\title{
REFINING THE CHRONOLOGY FOR WEST POLYNESIAN COLONIZATION: NEW DATA FROM THE SAMOAN ARCHIPELAGO
}

3 Jeffrey T. Clark ${ }^{1}$, Seth Quintus ${ }^{2}$, Marshall Weisler ${ }^{3}$, Emma St Pierre ${ }^{3}$, Luke Nothdurft ${ }^{4}$, Yuexing $4 \quad$ Feng $^{5}$

$5{ }^{1}$ Department of Sociology and Anthropology, North Dakota State University, Fargo, ND 58018, 6 USA

$7 \quad{ }^{2}$ Department of Geosciences, North Dakota State University, Fargo, ND 58018, USA

$8 \quad{ }^{3}$ School of Social Science, University of Queensland, St Lucia, Qld 4072 Australia

$9{ }^{4}$ School of Earth, Environmental and Biological Sciences, Queensland University of Technology, 10 GPO Box 2434, Brisbane, Qld 4001 Australia

11 Radiogenic Isotope Laboratory, School of Earth Sciences, University of Queensland, St Lucia, 12 Qld 4072 Australia

\section{Abstract}

15 The timing and unprecedented speed of the Lapita migration from the western edge of Oceania 16 to western Polynesia in the Central Pacific have long been of interest to archaeologists. The 17 eastern-most extent of that great human migration was the Samoan Archipelago in West 18 Polynesia, although critical questions have remained about the timing and process of Samoan 19 colonization. To investigate those questions, we carried out a Bayesian analysis of 19 20 radiocarbon dates on charcoal and 8 uranium-thorium (U-Th) series coral dates from four 21 archaeological sites on Ofu Island in the eastern reaches of Samoa. The analysis indicates initial 22 settlement of Ofu at 2717-2663 cal BP (68.2\%) by people using Plainware rather than the 23 diagnostic dentate-stamped Lapita pottery. This date range indicates that there is not a 24 significant chronological gap between Lapita and Plainware sites in Samoa, which holds 25 implications for modeling the settlement process in the Central Pacific.

26 Key Words: Samoa, Lapita, colonization, radiocarbon, Uranium-Thorium, Bayesian

27 Corresponding author: J.T. Clark; e-mail address: Jeffrey.Clark@ndsu.edu 


\section{INTRODUCTION}

32 Studies of human migration and colonization are a hallmark of archaeological inquiry. The last, and arguably greatest, migration in world prehistory was the expansion of humans across the far-

34 flung islands of Oceania. The process and timing of that migration have been debated since 35 European explorers entered the region, and that interest has only intensified as archaeological

36 evidence has accumulated. Of particular importance has been the migration of the Lapita peoples

37 (cf. Kirch 1997) identified, most notably, by a unique dentate-stamped pottery. However, the

38 term Lapita has been expanded by some to encompass an entire cultural complex (Green 1979).

39 Lapita cultural elements appear to have developed in the far western Pacific, with populations migrating into Remote Oceania (east and south of the Solomon Islands) over the course of a few centuries, and spreading into the Central Pacific (Fiji and West Polynesia). With the discovery of Lapita sherds at the Mulifanua site on 'Upolu Island, the Samoan Archipelago marks the eastern extent of Lapita migrations. But, despite decades of searching by archaeologists, Mulifanua still stands as the only site in Samoa to yield dentate-stamped Lapita ceramics. Many other sites have been found, however, that have produced Plainware (i.e., undecorated) ceramics, some of which appeared to be contemporaneous with Mulifanua. In recent years, prior radiocarbon determinations have been re-evaluated based on the application of "chronometric hygiene" protocols, with many dates rejected as unreliable. If these dates are removed from consideration, then a chronological gap lies between Mulifanua (and other Lapita sites in Tonga and Fiji) and the Plainware sites of Samoa. Thus, these re-evaluations of chronology raise important questions about the significance of the Samoan Archipelago in Lapita-era migration.

To address these questions, we apply a Bayesian analysis to 27 pre-2000 cal BP radiocarbon and Thorium-230 dates from four sites on Ofu Island, Manu'a Group, American Samoa. We then interpret the results in the context of West Polynesian prehistory. Using Ofu Island as a proxy, we provide a chronology for the colonization of the Manu'a Group on the eastern margin of the

56 Samoan Archipelago.

\section{CONTEXT}

58 The Samoan Archipelago lies in West Polynesia and comprises eight major inhabited islands that, due to Western colonial intervention, are now separated into the Independent State of

60 Samoa in the west ('Upolu, Savai'i, Manono, and Apolima islands) and the U.S. Territory of

61 American Samoa in the east (Tutuila, Aunu'u, Ofu, Olosega, Ta'u, Swains, and Rose Atoll) (Fig.

62 1). The Manu'a Group, which is constituted by Ofu, Olosega, and Ta' $u$ islands, forms the eastern

63 extent of inhabited islands in the archipelago. Although the Manu'a islands are small in area,

64 they are classified as high volcanic islands. Ofu $\left(7 \mathrm{~km}^{2}\right)$ and Olosega $\left(5 \mathrm{~km}^{2}\right)$ are separated by

65 less than $100 \mathrm{~m}$ while Ta'u $\left(39 \mathrm{~km}^{2}\right)$ is only $14.5 \mathrm{~km}$ to the southeast, so there is inter-visibility

66 and relatively easy travel between the islands. These are the youngest islands in the archipelago,

67 and their coastlines have undergone considerable change over the last 3,000 years due to 


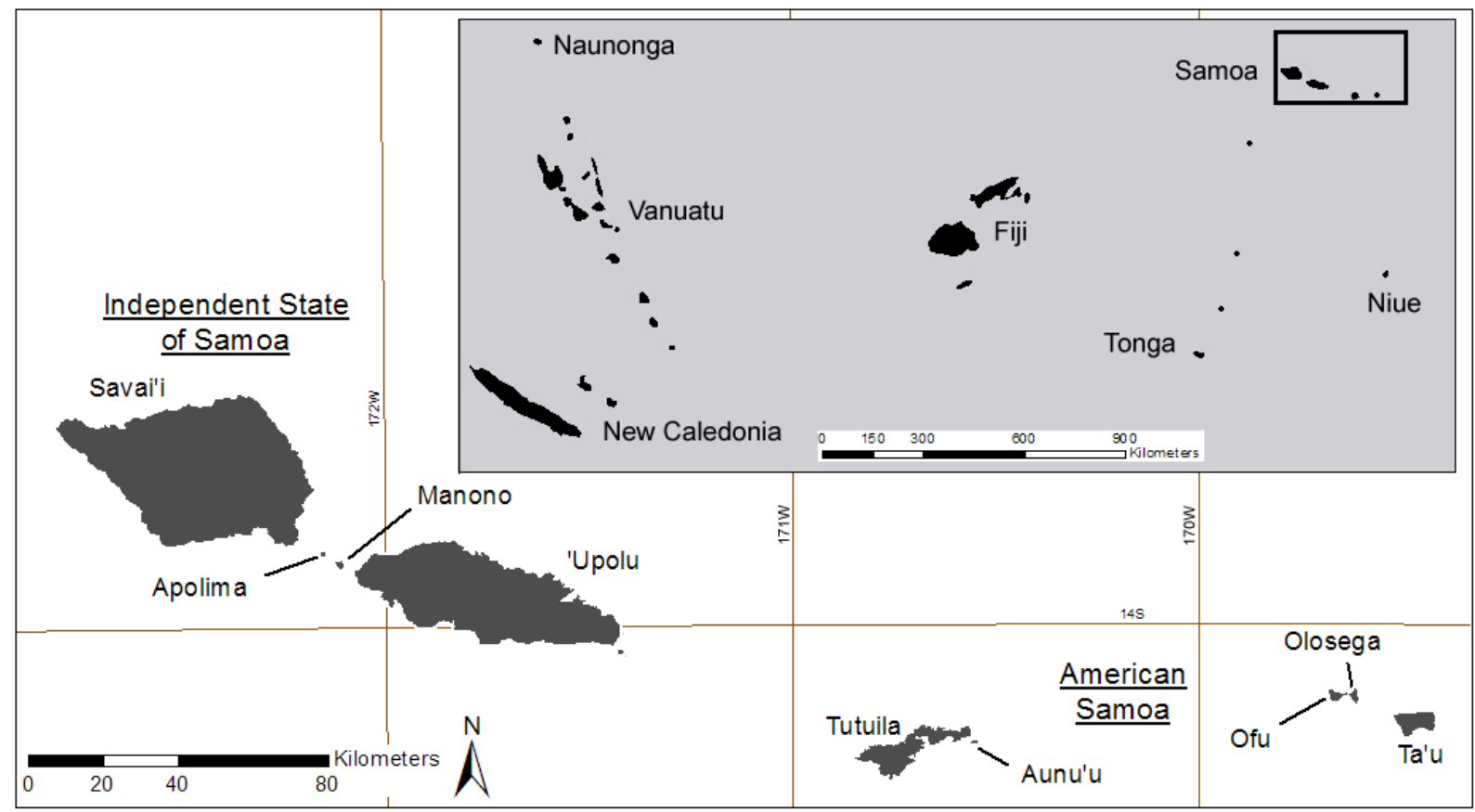

Fig. 1. Map of the Samoan Archipelago, with inset of the Central Pacific. Map data from ESRI, Inc.

Lapita ceramics first appear in the Bismarck Archipelago of the Western Pacific possibly as early as 3470-3250 cal BP (Denham et al. 2012; Specht et al. 2014) and spread into Remote Oceania about 3000 cal BP (Petchey et al. 2014; Petchey et al. 2015; Sheppard et al. 2015). Lapita populations have been regarded as the first colonists of the Fiji-West Polynesia region and ancestral to all later Polynesians (e.g., Golson 1961; Green 1979). Based on recent chronological assessments, Lapita colonization of Fiji-West Polynesia occurred rapidly and probably no earlier than 3000 cal BP (Anderson and Clark 1999; Burley et al. 2010; Nunn and Petchey 2013). Subsequently, ceramic decoration was largely lost, as Lapita ceramics were replaced with Plainware. The claim that Samoa is part of the Lapita horizon is based on the discovery of a site at Mulifanua, on the western coast of 'Upolu Island. That site is now underwater - the result of Holocene subsidence (Dickinson and Green 1998) - but was fortuitously discovered when dredging a ferry harbor. Archaeological investigation of in situ deposits has not taken place, but cultural remains from the site recovered from dredge piles include Lapita sherds in an Eastern Lapita decorative style characteristic of sites in Fiji and Tonga (Green 1974; Petchey 2001). Also recovered were shells and a turtle bone that provide the only dates for the site. Based on the critical evaluation of these dates, Petchey (2001:67) suggested that Mulifanua was settled around 2800 BP. However, there are still uncertainties with the dates: the association of the dated material with the cultural deposit; the stratigraphic position of dated samples; the reliability of the date on that turtle bone specimen; and large standard deviations of the shell dates. 
91 Consequently, chronometric dates of the colonization and abandonment of Mulifanua remain in

92 question. Petchey's most compelling argument for $2800 \mathrm{BP}$ is stylistic similarities of the

93 Mulifanua Lapita decorative elements with those found at sites in Fiji and Tonga, and given what

94 we now know of the chronologies of settlement in those archipelagos, a date of $2800 \mathrm{BP}$ is

95 reasonable (see below).

96 Numerous archaeological projects in Samoa over the last several decades have failed to locate

97 additional archaeological deposits with Lapita ceramics. Sites dated to 3000-2800 BP, or earlier,

98 and therefore contemporaneous with Mulifanua and other Central Pacific Lapita sites, have

99 yielded only Plainware ceramics: 'Aoa (Clark and Michlovic 1996), Aganoa, and Utumea

100 (Moore and Kennedy 1999) on Tutuila, and To'aga on Ofu (Kirch and Hunt 1993). Other sites

101 lacking dentate-stamped sherds that may date before 2500 cal BP were reported from Manono

102 and elsewhere on 'Upolu (Jennings and Holmer 1980). Many other Plainware sites have been

103 documented in the archipelago, but typically date to the mid-to-late first millennium and later,

104 thus post-dating the Lapita era.

105 In recent years the radiocarbon determinations from the Plainware sites have been re-evaluated

106 based on chronometric hygiene protocols (Rieth 2007; Rieth and Hunt 2008; Rieth et al. 2008).

107 Those studies rejected many dates, including the early (pre-2500) Plainware dates, based on

108 large standard deviations, dates on unidentified wood charcoal, and/or stratigraphic

109 inconsistencies. As a result, Rieth et al. (2008) report only 22 pre-2000 BP dates as reliable.

110 Removing the questionable dates from consideration results in a gap in the sequence between

111 Mulifanua and the settlement of the rest of the archipelago at 2400-2200 cal BP (Addison and

112 Morrison 2010) or 2500-2400 cal BP (Rieth and Hunt 2008; Rieth et al. 2008). Addison and

113 Morrison (2010) further propose that Samoa was settled twice, once by a Lapita group that

114 reached Mulifanua and perhaps a small number of sites that are currently submerged, and again

115 by a group carrying Plainware pottery that settled 'Upolu and all the other islands. Rieth and

116 Cochrane (2012:338) argue for "a severely diminished or absent prehistoric population in Sāmoa

117 after occupation of Mulifanua, until about 550-250 BC," but additional exploratory archaeology

118 focused on locating buried cultural deposits on coastal flats is warranted.

\section{3. METHODS AND RESULTS}

120 To build on the corpus of chronometric dates from Samoa, Clark and Quintus have carried out

121 archaeological investigations at three sites on the island of Ofu: the Va'oto (AS-13-13) and

122 Coconut Grove (AS-13-37) sites on the Va'oto Plain at the southern tip of the island, and the Ofu

123 Village (AS-13-41) site on the west coast (Fig. 2). Additionally, we present eight new U-Th

124 series dates of coral samples collected from those sites. These data are combined with a set of

125 dates from the To'aga (AS-13-1) site on the south-central coast of Ofu reported by Kirch

126 (1993a). 


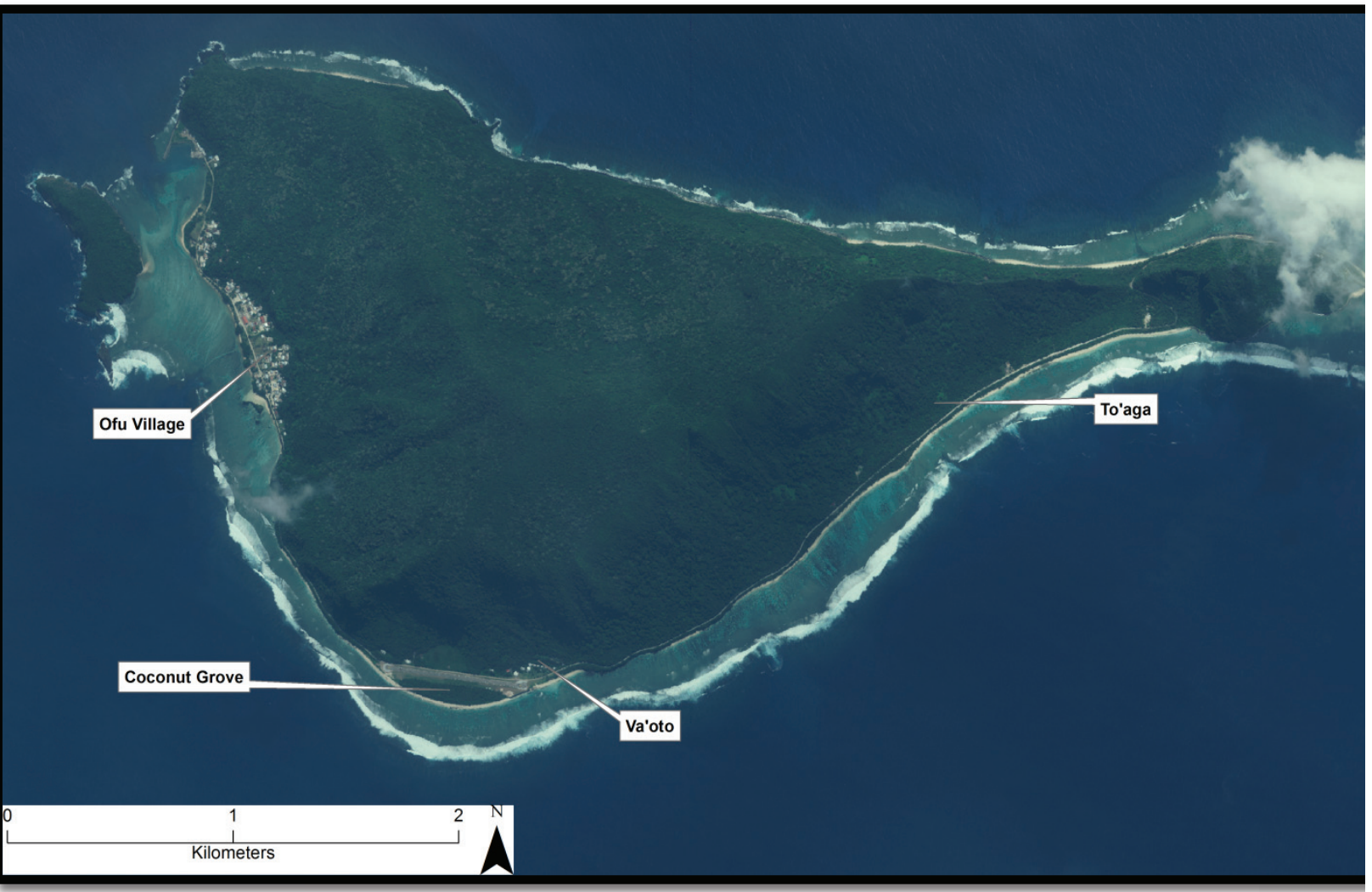

128 Fig. 2. The location of the four sample locations on Ofu Island discussed in the text. Note that these sites are located near the widest stretches of fringing reef.

\section{$130 \quad 3.1$ Radiocarbon Dating}

131 The combined dataset consists of 19 pre-2000 cal BP charcoal radiocarbon dates from four sites 132 on Ofu: 11 from Va'oto, 2 from Coconut Grove, 2 from Ofu Village, and 4 from To'aga (Fig. 2;

133 Table 1). The charcoal samples from Va'oto, Coconut Grove, and Ofu Village were dated at Beta 134 Analytic using an accelerator mass spectrometer (AMS). Charcoal samples from these sites were 135 taken in situ and point-plotted in 3D space. Three additional samples from charcoal residue on 136 ceramic sherds, all from the Va'oto site, were taken and dated by Susan Eckert. Most charcoal 137 samples were not identified prior to submission for analysis, but short-lived samples, specifically 138 Cocos nucifera endocarp (coconut shell), have been dated from all three sites. All identified 139 samples were examined by Jennifer Huebert at the University of Auckland. Five samples -2 140 from Ofu Village, 1 from Coconut Grove, and 2 from Va'oto - were identified as short-lived 141 taxa. All conventional radiocarbon dates were calibrated in Oxcal 4.2 (Bronk Ramsey 2009) 142 using the IntCal 2013 calibration curve (Reimer et al. 2013). Charcoal dates from prior 143 investigation at To'aga (Kirch 1993a), which were dated using standard radiocarbon techniques, 144 were recalibrated for this analysis. As such, those samples from To'aga have significantly higher 145 error ranges relative to samples from the other Ofu sites ( $> \pm 100$ compared to \pm 30 or \pm 40 ). 
146 Shell dates from previous research at To'aga were not used in this analysis, which we restricted

147 to charcoal for consistency. It should be noted, though, that preliminary checks have shown that

148 the inclusion of the remaining pre-2000 cal BP shell dates would have little effect on the results

149 of this analysis.

\section{$150 \quad 3.2$ Uranium and Thorium (U-Th) Dating}

151 Pristine, culturally unmodified branches and two coral abraders of Acropora spp. coral were 152 collected: (1) in situ within cultural layers or (2) at the boundary of the lowest cultural layer and 153 sterile sedimentary deposit (paleo beach). In the first instance, coral samples date the formation 154 of the cultural layers as unmodified coral branches and abraders were added as part of the layer 155 matrix, while in the latter, coral dates provide a terminus post quem for the formation of the 156 earliest cultural layer (e.g., sample 2014-19). Branch samples were first examined to determine 157 the general state of preservation. To exclude samples with diagenesis, coral branches with 158 obvious water rounding were not considered further for U-series dating. Only coral branches that 159 exhibited sharp and well preserved verrucae were selected. These pristine-appearing branches 160 were subsampled for analysis of diagenetic alteration from deleterious products including marine 161 aragonite and calcite cements, meteoric cements, and dissolution and extensive bioerosion using 162 Scanning Electron Microscopy (SEM) (Hua et al. 2015; Nothdurft and Webb 2009;). Small 163 representative pieces were cut with a diamond saw and analyzed with SEM for identifying pore 164 filling cements. The lab numbers and provenance information for the U-series dated coral 165 samples are presented in Table 2.

166 A subsample of material from each of the coral specimens was cut and the exterior corallites 167 removed with a diamond edged circular saw. Material was crushed with bone cutters and an 168 agate mortar and pestle to approximately $1 \mathrm{~mm}$ grain size. Cleaning procedures follow those 169 described in Clark et al. (2014a, 2014b) and were performed in an ultra-clean lab. Coral

170 fragments for analysis were examined under a microscope to select the cleanest coral pieces free 171 from alteration and clay or infilled cement contamination. SEM indicates that the skeletal 172 components of the majority of samples are unaltered with largely pristine skeletal aragonite.

173 Samples are generally pristine and the internal core of the coral skeletons considered unaltered.

174 In those samples that were affected by alteration, the diagenetic effects were minimal and 175 primarily confined to the exterior portions of the coral skeleton. The removal of the external

176 skeleton before crushing and microscopic vetting of the crushed coral fragments after

177 undertaking the $\mathrm{H}_{2} \mathrm{O}_{2}$ cleaning procedure eliminated any sample fragments that may have 178 contained altered material. For this reason, all samples were considered suitable for U-Th dating.

$179 \mathrm{U}$ and $\mathrm{Th}$ isotope ratios were measured on a $\mathrm{Nu}$ Plasma multi-collector inductively coupled 180 plasma mass-spectrometer (MC-ICP-MS) with a DSN-100 nebulizing system and a modified 181 CETAC ASX-110FR autosampler, at the Radiogenic Isotope Facility, University of Queensland 182 following procedures described in Clark et al. (2014a, 2014b). U-Th data in Table 3 shows ${ }^{232} \mathrm{Th}$ 
183 concentrations similar to values of other Pacific island corals of a similar age (e.g. Burley et al.

184 2012, Cobb et al. 2003, Weisler et al. 2006, Weisler et al. 2009). ${ }^{232}$ Th values range between

$1850.019 \mathrm{ppb}$ and $1.39 \mathrm{ppb}$, with an average concentration of $0.44 \mathrm{ppb}$. These values are relatively

186 low and indicate that initial ${ }^{230} \mathrm{Th}$ component from detrital ${ }^{232} \mathrm{Th}$ is minimal or negligible,

187 resulting in excellent age precision. All the samples fulfill the criteria, outlined in Scholz and

188 Mangini (2007), to identify diagenetic factors that affect both age precision and accuracy. These 189 include calcite content of less than $2 \%,{ }^{232} \mathrm{Th}$ concentrations less than $2 \mathrm{ppb}$, U concentrations

190 that fall within modern coral values (i.e. $2.5-3.5 \mathrm{ppm}$ ), and $\delta^{234} U$ that fall within modern

191 seawater and coral values (i.e. $147 \pm 5 \%$ ). Thus, the Samoan samples are considered reliable for

192 U-Th dating.

\section{$193 \quad 3.3$ Single Phase Bayesian Modelling}

194 The use of Bayesian analysis to determine precise chronologies for island colonization and 195 depositional sequences is becoming widespread in Oceania (Allen and Morrison 2013; Burley

196 and Edinborough 2014; Burley et al. 2015; Cochrane et al. 2013; Denham, et al. 2012; Nunn and 197 Petchey 2013; Petchey et al. 2015; Sheppard et al. 2015). Simply, Bayesian statistics allow one

198 to integrate prior information into the calculation of probability distributions for individual dates;

199 that prior information may be stratigraphic evidence or more general chronological controls.

200 Based on information included in the model, the program provides a quantitative assessment of 201 the accuracy of the model, i.e., the agreement index. The conventional recommendation is that 202 the agreement index should be above $60 \%$ for all samples and the model as a whole. If the 203 agreement index of an individual sample is less than $60 \%$, it may mean the sample is an outlier; 204 if the model agreement index is less than $60 \%$, the model could be invalid.

205 We integrate charcoal and coral dates into a single Bayesian model, facilitated by the use of 206 OxCal, to model the start date for the colonization of Ofu Island. For simplicity, we model island 207 colonization as a single uniform phase using the standard boundary command. This model 208 assumes no prior ordering of dates - all determinations are a random scatter of events in no 209 particular order - but evaluates all dates within a shared group to determine, for instance, the 210 probability that the statistical tails of some dates are the product of plateaus in the calibration 211 curve. This is particularly important for this time period, which is significantly affected by the 212 Iron-Age calibration plateau. The integration of coral dates with AMS radiocarbon dates in the 213 model may allow us to overcome the deficiencies of wood charcoal dates within that time range.

214 Furthermore, it allows us to quantitatively assess the internal consistency of both coral and 215 radiocarbon dates. The single group analyzed is defined as all pre-2000 cal BP charcoal and coral 216 dates from Ofu.

217 Three iterations of a Bayesian model were run to determine the timing of initial colonization of 218 Ofu Island. Two of the coral dates (2014-15 and 2014-18) were excluded from analysis as they 219 stem from pre-colonization contexts based on stratigraphic evidence. They were dated to address 
220 questions regarding landscape formation processes. All other samples are interpreted to date 221 human activity, either by association or because the fresh coral finger was modified into an 222 artifact (2014-16 and 2014-24). Sample 2014-19, an unmodified fresh coral finger, is of

223 particular importance given that it is located at the interface of sterile beach sand and the basal

224 cultural deposit at Coconut Grove.

225 The first iteration consisted of all coral and charcoal dates deemed to be associated with human 226 activity $(\mathrm{n}=27)$. The initial run of the model resulted in a modelled start date of 2875-2649 cal 227 BP (95.4\%) (Fig. 3). All but one determination returned agreement indices above 60\%, and the 228 model had an overall agreement of $75 \%$. The lone radiocarbon date with an index below the 229 threshold is the earliest charcoal date from To'aga (Beta-35601, A=14\%). Such a low agreement 230 index, along with visual inspection, suggests that the sample is an outlier, perhaps because it was 231 wood with in-built age. The outlier was removed from the phase and a second iteration of the 232 model was run (Fig. 4). This resulted in a higher overall model agreement ( $\mathrm{A}=91.3 \%)$, and all 233 dates have individual agreement indices above $60 \%$. This iteration resulted in a shorter modelled 234 start date of 2763-2645 cal BP (95.4\%). To ensure reliable results, a third iteration of the model 235 was run that included only determinations derived from either short-lived charcoal $(\mathrm{n}=5)$ or coral 236 from cultural deposits, as defined above $(\mathrm{n}=8)$ (Fig. 5). Again, the model returned a high overall 237 agreement index ( $\mathrm{A}=99.3$ ), and all individual agreement indices were over 95\%. The modelled 238 start date was very similar to that modelled in the second iteration, with a 95.4\% HPD range of $2392774-2647 \mathrm{cal} \mathrm{BP}$ and a $68.2 \%$ range of $2717-2663 \mathrm{cal} \mathrm{BP}$. 


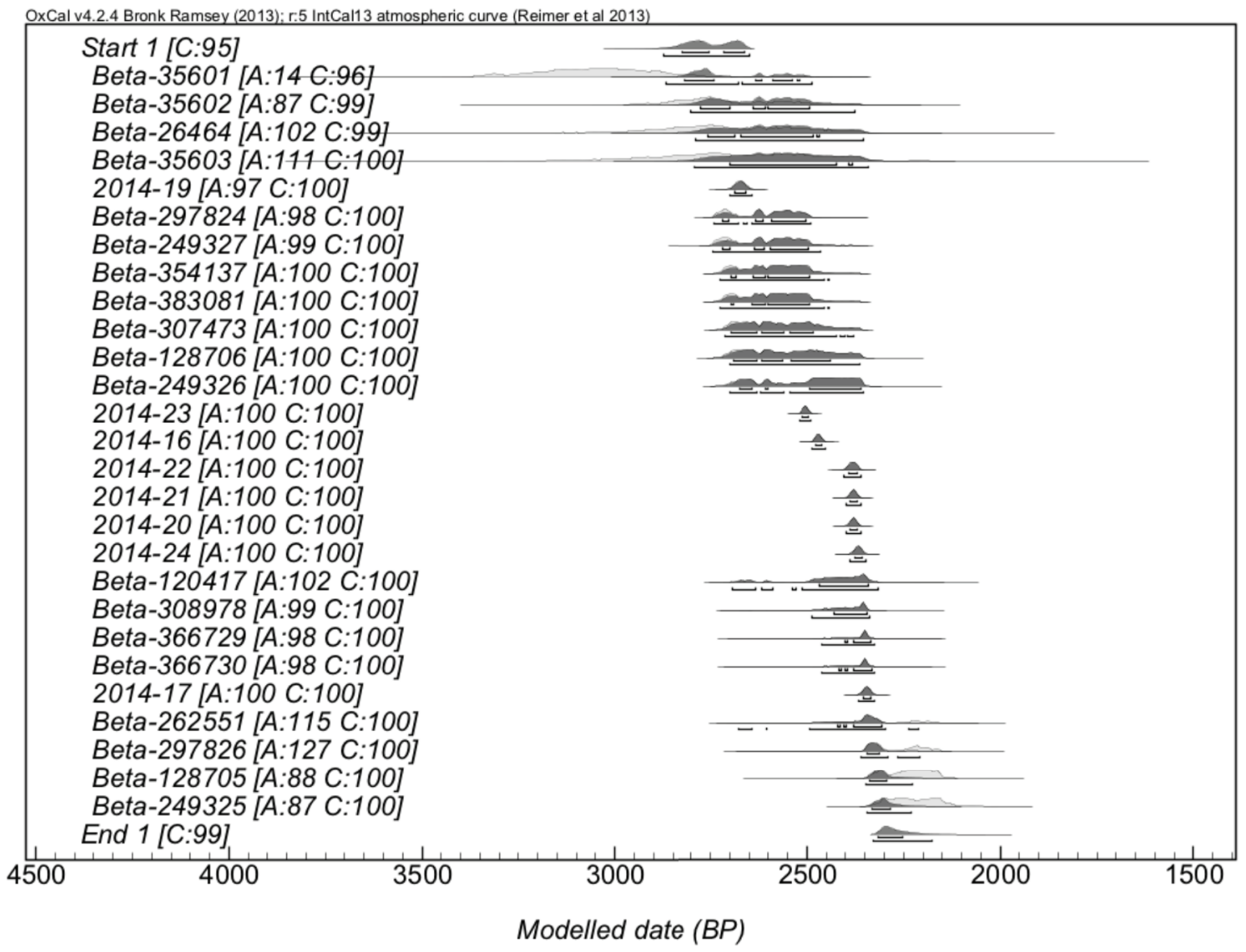

241 Fig. 3. Single Phase Bayesian analysis of all culturally-assocated pre-2000 BP coral and charcoal dates 242 from Ofu Island. Note the agreement index of Beta-35601. 


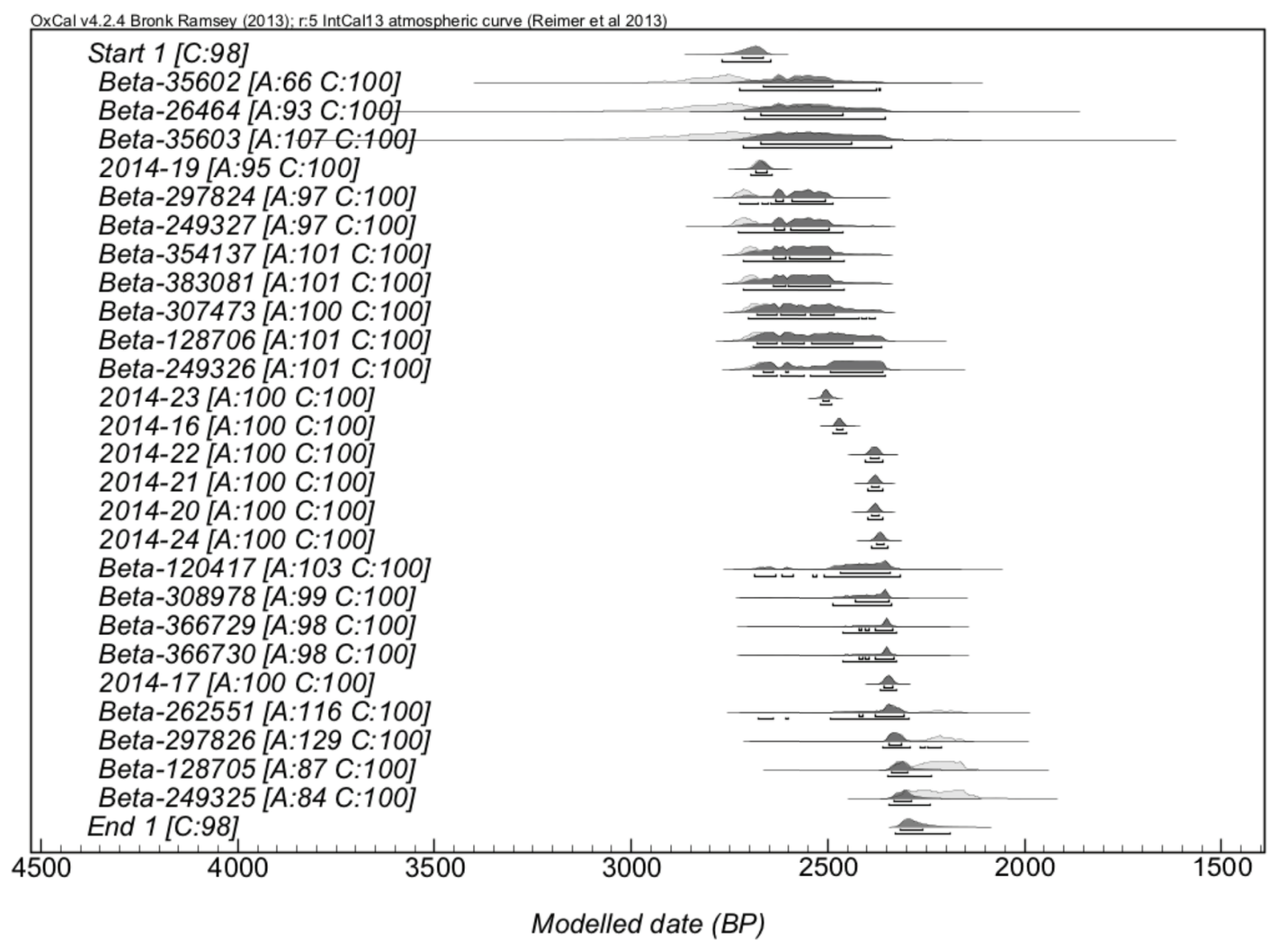

244 Fig. 4. Single Phase Bayesian model of all culturally-associated pre-2000 cal BP dates from Ofu Island 245 excluding the interpreted outlier Beta-35601. 


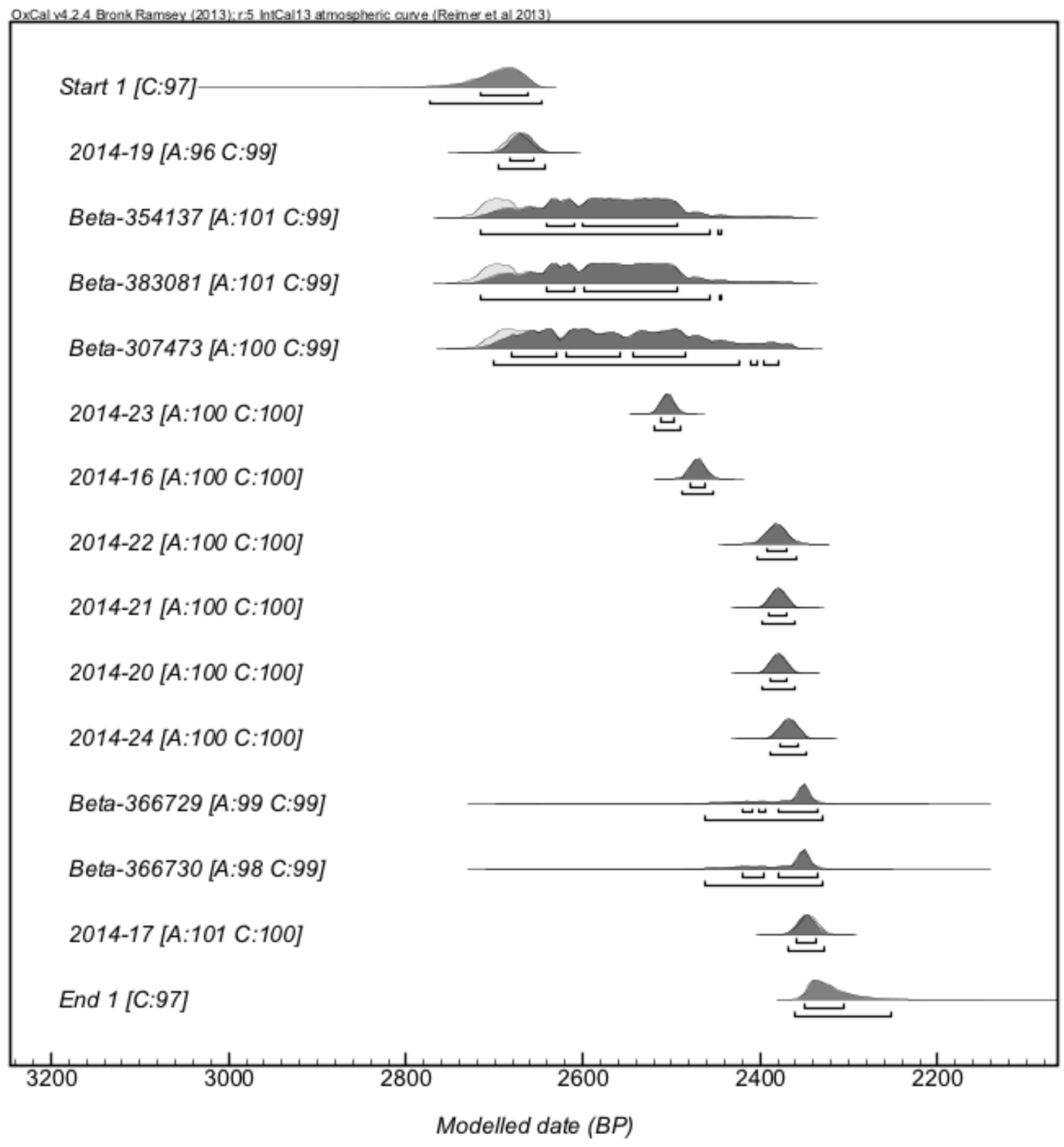

247 Fig. 5. Single Phase Bayesian model of all culturally-associated coral and short-lived charcoal samples.

248 This model had the highest overall agreement index of any iteration. 


\section{DISCUSSION}

250 Our Bayesian analysis of charcoal and coral dates from Ofu Island indicates colonization no later than 2650 cal BP. We favor the modeled range of 2717-2663 cal BP (68.2\%) as the most precise period bracketing colonization. This range is influenced by four dates on short-lived material: one on coral and one on coconut endocarp charcoal from Coconut Grove, and two on coconut endocarp charcoal from Ofu Village. The three charcoal dates have large ranges associated with the Iron-Age calibration plateau and the coral age is interpreted as marking the first settlement of Coconut Grove based on stratigraphic context and consistency with the short-lived charcoal date from the same deposit. We add that the four sites covered in this analysis represent the areas of coastal lowlands most likely to have been available for early occupation, and it seems unlikely to us that significantly earlier colonization (before the $95.4 \%$ range of $2774-2647$ cal BP) took

260 place at any other location on the island.

261 Based on these data, Ofu Island appears to have been settled after Lapita colonization of 'Upolu,

262 although the dates from Ofu overlap with those from Mulifanua when using the 95.4\% HPD 263 range (see Petchey 2001). If one rejects or sets aside the earliest dates on Tutuila from 'Aoa, 264 Aganoa, and Utumea (Clark and Michlovic 1996; Moore and Kennedy 1999) due to unidentified wood and questions of context as argued by some (Rieth 2007; Rieth and Hunt 2008; Rieth et al. 2008), then Ofu would appear to have been colonized prior to Tutuila. More importantly, the modelled colonization date for Ofu presented here, taken in conjunction with all pre-2000 cal BP determinations for Samoa, does not support a significant gap in the Samoan sequence between Lapita colonization on 'Upolu and the later Plainware occupation in the archipelago as previously suggested (e.g., Addison and Morrison 2010; Rieth 2007; Rieth and Hunt 2008; Rieth et al. 2008). The date of colonization of Ofu allows us to quantify the period of migration through the Central Pacific and place Manu'a more confidently within that span.

Recent reassessment of dates from the Bismarck Archipelago by Denham et al. (2012) provide an initial date for the appearance of Lapita ceramics at 3470-3250 cal BP (68.2\%), although those dates may reflect, to some degree, an in-built age due to old-wood effect. Lapita populations expanded further into the Pacific to colonize islands in Remote Oceania. Denham et al. (2012:44) put the colonization of Vanuatu at 3250-3100 cal BP (68.2\%) and Fiji at 3130-3010 cal BP $(68.2 \%)$, but dates used to construct that chronology are either on unidentified wood with possible in-built age, from problematic context, or are anomalous relative to sites in proximity (Nunn and Petchey 2013; Sheppard et al. 2015:34-35). Sheppard et al. (2015), therefore, suggest that Remote Oceania was not colonized until 3000 cal BP or shortly thereafter, although one site in Vanuatu (Mauké on Aore Island Espiritu Santo), and one in the Loyalty Islands (Kurin on Maré) may be slightly earlier. The earliest sites in Fiji now appear to be Bourewa on Viti Levu Island and Matanamuani on Naigani Island. Nunn and Petchey (2013) critically reassessed the early dates for Bourewa using a Bayesian analysis, putting the site colonization at 2866-2771 cal BP (95.4\%). Dates for Matanamuani were recently reanalyzed by Sheppard et al. (2015) through 
287 a Bayesian model, which revealed an outlier that Irwin et al. (2011) had initially identified as 288 inconsistently old, possibly reflecting old-wood effect. When that date is removed from 289 consideration, the Bayesian analysis indicates "an upper boundary for the site of 3001-2790 cal 290 BP (95\% HPD)" (Sheppard et al. 2015:32).

291 In West Polynesia, Burley and colleagues have proposed that in Tonga, the Nukuleka site, on 292 Tongatapu, constitutes the founding Lapita colony of Tonga. Radiocarbon dates for Nukuleka 293 document initial occupation at 2900-2850 cal BP, but subsequent Bayesian analysis pairing AMS 294 and U-Th dates of Nukuleka (Burley et al. 2012), particularly a U-Th date on a coral file, further 295 refined the colonizing date to $2846-2830$ cal BP. Recently, those analytical techniques were 296 applied to other Lapita sites in the Tongan Archipelago with the results showing subsequent settlement of the islands to the north 70-90 years later, with several islands colonized instantaneously in the Ha'apai Group, in the Vava'u Group, and possibly as far away as Niuatoputapu (Burley et al. 2015). The age of Mulifanua at ca. 2800 BP proposed by Petchey (2001) falls within the Lapita sequence of Tonga, and there is marked temporal proximity of Ofu to Mulifanua.

Taking 3000 cal BP as the beginning of the colonization of Remote Oceania and the colonization of Ofu as the end provides a timespan of the migration of 280-340 years (calculated based on $68.2 \%$ range). Lapita colonization of western Remote Oceania may have been completed within 14 generations (at 20 years each). Sheppard and colleagues (Sheppard 2011; Sheppard et al. 2015; Sheppard and Walter 2006) have argued that the speed of the Lapita colonization from the Bismarck Archipelago in the far west out to the Reef/Santa Cruz group in Remote Oceania was so fast that it can only be explained by invoking a leap-frog movement. Once in Remote Oceania, migration farther east continued in "an almost continuous expansion, possibly through a series of leap-frogs" (Sheppard et al. 2015:35). Similarly, because some of the pottery at the Nukuleka site came from an island to the west of Fiji, Burley and colleagues (Burley and Connaghton 2007; Burley et al. 2010; Burley and Dickinson 2010) view the Tonga colony as also suggesting a leap-frog settlement process. Sheppard et al. (2015:35) further argued that given this speed of expansion, there is now no evidence of population growth as a driver for the migration from the western Pacific out to Fiji. We conclude that the short timespan documented here for the migration beyond Fiji to Tonga and the eastern-most islands of Samoa also strongly argues against a demographically driven explanation for the colonization of West Polynesia, whether by Lapita or Plainware populations. This argument applies regardless of whether the colonization process was one of leap-frogging or direct, down-the-line movement; but if the

321 Population size may have played another role, however, which is in ending Lapita-era (i.e., 322 Lapita or Plainware) migration. As others have argued, settlement of Samoa may have stretched 323 colonizers to their limit (Addison and Morrison 2010), and this may have caused the initial 324 populations inhabiting the archipelago to remain small and somewhat isolated (Cochrane et al. 
2013). The suggestion that the migration may have been running out of steam, so to speak, is highlighted by the difference between the length of time from the beginning of the colonization of Remote Oceania to the settlement of Tonga ( $\approx 154-170$ years), as modelled by Burley et al. (2012) (2846-2830 cal BP), and the length of time from settlement of Tonga to the colonization of Ofu ( $\approx 129-183$ years), a considerably shorter distance.

The dates proposed here for Ofu also hold implications for understanding other aspects of West Polynesian colonization. At the $95.4 \%$ confidence level, the Ofu (Plainware) date range (27742647 cal BP) closely approaches, and possibly overlaps with, the occupation of Mulifanua (Lapita). At the very least, then, the time frame for a gradual transformation of Samoan Lapita to a Polynesian Plainware narrows considerably (Green 1974:253). In Tonga, Burley and colleagues propose that the cessation of Lapita dentate stamping and the transition to Plainware ceramics took place over periods of " 129 to158 years on Tongatapu, 32 to 49 years in Ha'apai, and 51 to 82 years in Vava' 'u" (Burley et al. 2015:11). Such a transition in Samoa may also have been fairly rapid. But, while there is evidence of a transition in Tonga, none of the first millennium BC sites in Samoa have presented evidence of a decorated-to-plain transition. It is important to note that the modelled colonization date for Ofu of $2717-2663 \mathrm{cal} \mathrm{BP}$ at $68.2 \%$ overlaps with the Burley et al. (2015) dates of Lapita ceramic loss in Tonga (at $68.2 \%$, cal BP) of 2709-2680 on Tongatapu, 2728-2716 for Ha'apai, and 2703-2683 for Vava'u. If the Ofu colonizers originated somewhere in Tonga (which is still uncertain), they may have embarked after, or in the dying stage of, decorative ceramic applications. Thus, this temporal correlation supports a migration scenario in which Ofu was settled soon after the loss of Lapita ceramics from Tonga.

Alternatively, it is conceivably that sites with Lapita pottery or showing such a transition to Plainware may lie submerged along the coasts of 'Upolu and Savai' $i$, but submergence of sites is not indicated for Tutuila or Manu'a in either the geomorphological model of Dickinson and Green (1998) or the documented locations of early sites (Clark and Michlovic 1996; Kirch and Hunt 1993; Moore and Kennedy 1999; Quintus et al. 2015). On those islands, sites may yet be found buried under talus and colluvium back from the modern shoreline (Kirch 1993b), but where such areas have been explored thus far, only Plainware has been found. Another proposed explanation for the apparent absence of sites with Lapita or transitional ceramics - and scarcity of pre-2500 BP settlements of any type - is limited occurrence of suitable coastal plains at that time (Rieth et al. 2008; Cochrane et al. 2015). But, the founding populations are likely to have been quite small (e.g., Addison and Morrison 2010), and therefore would not require much in the way of a coastal flat. That certainly is the case with the Ofu sites and is overwhelmingly the case with early colonization of low coral atolls that typify settlement of the smallest of island landscapes (Weisler et al. 2012). Moreover, two non-culturally affiliated coral dates from Ofu, samples 2014-15 and 2014-18, indicate that the coastal landscape of Ofu onto which humans settled was available by the end of the $2^{\text {nd }}$ millennium BC. Certainly the conditions on each island in the archipelago were unique due to differing geological forces and geomorphological 
364 configurations, but while limited suitable land constrained colonization opportunities in Samoa,

365 it did not prohibit settlement.

366 It is now clear that while some islands in the Samoan archipelago, notably 'Upolu, were

367 colonized by Lapita people with dentate-stamped pottery, other islands, i.e., Ofu, were first

368 settled by people making only Plainware pottery. Whether these conditions reflect colonization

369 of Samoa by one group or two groups remains unresolved. The single-group model gains some

370 support in closing the time gap between decorated and plain assemblages. At the same time, the

371 same gap closure, in conjunction with the absence of stylistic transition, may be regarded as still

372 indicating two distinct groups, one Lapita and one Plainware. The debate as to the number of

373 colonization events and peoples for Samoa will require analysis of a range of data including

374 detailed comparisons of ceramic assemblages amongst sites in Samoa and Tonga, and

375 petrographic and/or geochemical analysis of ceramic constituents to identify exotic or locally

376 made pottery. Detailed analyses of the ceramic assemblages from the Va'oto, Coconut Grove,

377 and Ofu Village sites have not been completed, but we can say that the assemblages are broadly

378 comparable with one another and with the assemblages from To'aga described by Hunt and

379 Erklens (1993). How those assemblages compare with the Plainware assemblages from other

380 sites in Samoa and Tonga remains to be determined.

\section{5. CONCLUSIONS}

382 The presence of a single site with Lapita ceramics in the Samoan Archipelago together with 383 reevaluations of previously published dates have raised questions as to the continuity between

384 Lapita and Plainware sites in Samoa, and about the precise age of that colonization(s). Our 385 results provide preliminary answers to these questions. First, data from Ofu fills a gap in the 386 chronological sequence of the archipelago created by previous chronometric hygiene protocols. 387 While this still leaves open the possibility that multiple groups were involved in the human 388 settlement of Samoa, it does refute the proposal that there was a substantial amount of time 389 between these possible different settlement events. Second, our model indicates that Ofu was 390 colonized sometime within 2774-2647 cal BP (95.4\%) or perhaps more narrowly, 2717-2663 cal 391 BP (68.2\%). That such a date overlaps with modelled dates of the loss of dentate-stamped 392 decoration in Tonga may explain the absence of Lapita pottery on Ofu, although other 393 explanations are also possible. Thus, the data presented here contribute to the continuing efforts 394 to understand the colonization of the Pacific. The precision allowed by the U-Th dating of coral, 395 especially when input into a Bayesian model, creates opportunities for more robust models of 396 colonization. In particular, they provide a precise duration of Lapita-era migration and the 397 changing pace of island colonization. The Samoan Archipelago, and more specifically the 398 Manu'a Group of American Samoa, inhabits an important place as the eastern Oceanic extent of 399 arguably the most rapid maritime human migration in world prehistory. 


\section{Acknowledgments}

402 We are deeply grateful to the people of Ofu Island, American Samoa for allowing us to conduct

403 our research, and for their hospitality, cooperation, and assistance during our time on their

404 beautiful and enchanting island. This research was supported in part by the U.S. National

405 Science Foundation (Grant No. 1229417). Any opinions, findings, and conclusions or

406 recommendations expressed in this material are those of the author(s) and do not necessarily

407 reflect the views of the National Science Foundation. Additional support was provided by North

408 Dakota State University. Emma St Pierre's postdoctoral fellowship was supported by strategic

409 funding from the Deputy Vice Chancellor, University of Queensland to Weisler. We thank Tara

410 Clark (University of Queensland) for input and assistance while processing coral samples for U-

411 series dating. We also thank Susan Eckert for sharing her dating results on pottery sherds from

412 our Va'oto collection.

\section{References}

414 Addison, D.J., Morrison, A.E., 2010. The Lapita settlement of Samoa: is a continuous occupation 415 model appropriate? in: Wallin, P., Martinsson-Wallin, H. (Eds.), The Gotland Papers: Selected 416 Papers from the VII International Conference on Easter Island and the Pacific: Migration, 417 Identity, and Cultural Heritage. Gotland University Press, Gotland, pp. 359-375.

418 Allen M.S., Morrison, A.E., 2013. Modeling site formation dynamics: geoarchaeological, 419 chronometric and statistical approaches to a stratified rockshelter sequence, Polynesia. Journal of 420 Archaeological Science 40, 4560-4575.

421 Anderson, A., Clark, G., 1999. The age of Lapita settlement in Fiji. Archaeology in Oceania 34, $422 \quad 31-39$.

423 Anderson, A., Chappell, J., Gagan, M., Grove, R., 2006. Prehistoric maritime migration in the 424 Pacific islands: an hypothesis of ENSO forcing. The Holocene 16, 1-6.

425 Bronk Ramsey, C., 2009. Bayesian analysis of radiocarbon dates. Radiocarbon 51, 337-360.

426 Burley D.V., Connaughton, S.P., 2007. First Lapita settlement and its chronology in Vava'u, 427 Kingdom of Tonga. Radiocarbon 49, 131-137.

428 Burley D.V., \& W.R. Dickinson, 2010. Among Polynesia’s first pots. Journal of Archaeological 429 Science 37, 1020-1026.

430 Burley D.V., Edinborough, K., 2014. Discontinuity in the Fijian archaeological record supported 431 by a Bayesian radiocarbon model. Radiocarbon 56, 295-303. 
432 Burley, D.V., Barton, A., Dickinson, W.R., Connaughton, S.P., Taché, K., 2010. Nukuleka as a 433 founder colony for west Polynesian settlement: new insights from recent excavations. Journal of 434 Pacific Archaeology 1, 128-144.

435 Burley D. V., M. I. Weisler, \& J-x Zhao, 2012. High Precision U-Th Dating of First Polynesian 436 Settlement. PLoS ONE 7(11): e48769. doi:10.1371/journal.pone.0048769

437 Burley, D.V., Edinborough, K., Weisler M., Zhao, J-x., 2015. Bayesian modeling and 438 chronological precision for Polynesian settlement of Tonga. Plos ONE 10:e0120795. 439 doi:10.1371/journal.pone.0120795

440 Clark, J.T., Michlovic, M.G., 1996. An early settlement in the Polynesian homeland: 441 Excavations at 'Aoa valley Tutuila Island, American Samoa. Journal of Field Archaeology 23, $442 \quad 151-168$.

443 Clark, T.R., Roff, G., Zhao, J.X., Feng, Y.X., Done, T.J., Pandolfi, J.M., 2014a. Testing the 444 precision and accuracy of the U-Th chronometer for dating coral mortality events in the last 100 445 years. Quaternary Geochronology 23, 35-45.

446 Clark, T.R., Zhao, J.X., Roff, G., Feng, Y.X., Done, T.J., Northdurft, L.D., Pandolfi, J.M., 447 2014b. Discerning the timing and cause of historical mortality events in modern Porites from the 448 Great Barrier Reef. Geochimica et Cosmochimica Acta 138, 57-80.

449 Cobb, K.M., Charles, C.D., Cheng, H., Kastner, M., Edwards, R.L., 2003. U-Th-dating living 450 and young fossil corals from the central Pacific. Earth and Planetary Science Letters 210, 91-

451 Cochrane, E.E., Kane, H., Fletcher III, C., Horrocks, M., Mills, J., Barbee, M., Morrison, A.E., 452 Tautunu, M.M., 2015. Lack of suitable coastal plains likely influenced Lapita ( 2800 cal. BP) 453 settlement of Sāmoa: Evidence from south-eastern 'Upolu. The Holocene, Online First, 1-10. 454 http:/hol.sagepub.com/content/early/2015/07/29/0959683615596841.full.pdf +html

455 Cochrane, E.E., Rieth, T.M., Dickinson, W.R., 2013. Plainware ceramics from Sāmoa: insights 456 into ceramic chronology, cultural transmission, and selection among colonizing populations. 457 Journal of Anthropological Archaeology 32, 499-510.

458 Denham, T., Bronk Ramsey, C., Specht, J., 2012. Dating the appearance of Lapita pottery in the 459 Bismarck Archipelago and its dispersal to Remote Oceania. Archaeology in Oceania 47, 39-46.

460 Dickinson, W.R., Green, R.C., 1998. Geoarchaeological context of Holocene subsidence at the 461 ferry berth Lapita site, Mulifanua, Upolu, Samoa. Geoarchaeology 13, 239-263.

462 Golson, J. 1961. Report on New Zealand, Western Polynesia, New Caledonia and Fiji. Asian 463 Perspectives 5, 166-180. 
464 Green, R.C., 1974. A review of portable artifacts from Western Samoa, in: Green, R.C., 465 Davidson, J.M. (Eds.), Archaeology in Western Samoa, Vol. II. Bulletin 7. Auckland Institute 466 and Museum, Auckland, pp. 245-275.

467 Green, R.C., 1979. Lapita, in: Jennings, J. D. (Ed.), The Prehistory of Polynesia. Harvard 468 University Press, Cambridge, pp. 27-60.

469 Hua, Q., Webb, G., Zhao, J-x, Nothdurft, L., Lybolt, M., Price, G., Opdyke, B., 2015. Large 470 variations in the Holocene marine radiocarbon reservoir effect reflect ocean circulation and 471 climatic changes. Earth and Planetary Science Letters 422, 33-44.

472 Hunt, T.L., Erklens, C., 1993. The To`aga ceramics, in: Kirch, P.V., Hunt, T.L. (Eds.), The 473 To'aga Site: Three Millennia of Polynesian Occupation in the Manu'a Islands, American Samoa. 474 Contributions of the University of California Archaeological Research Facility No. 51, Berkeley, 475 pp. 123-149.

476 Irwin, G., Worthy, T.H., Best, S., Hawkins, S., Carpenter, J., Matararba, S., 2011. Further 477 investigations at the Naigani Lapita site (VL 21/5), Fiji: excavation, radiocarbon dating and 478 palaeofaunal extinction. Journal of Pacific Archaeology 2, 66-78.

479 Jennings, J.D., Holmer, R.N., 1980. Chronology, in: Jennings, J.D., Holmer, R.N. (Eds.), 480 Archaeological Excavation in Western Samoa. Pacific Anthropological Records No. 32, 481 Honolulu, pp.5-10.

482 Kirch, P.V., 1993a. Radiocarbon chronology of the To'aga Site, in: Kirch, P.V., Hunt, T.L. 483 (Eds.), The To'aga Site: Three Millennia of Polynesian Occupation in the Manu'a Islands, 484 American Samoa. Contributions of the University of California Archaeological Research 485 Facility No. 51, Berkeley, pp. 85-92.

486 Kirch, P.V., 1993b. The To'aga site: modeling morphodynamics of the land-sea interface, in: 487 Kirch, P.V., Hunt, T.L. (Eds.), The To'aga Site: Three Millennia of Polynesian Occupation in the 488 Manu'a Islands, American Samoa. Contributions of the University of California Archaeological 489 Research Facility No. 51, Berkeley, pp. 31-42.

490 Kirch, P.V., 1997. The Lapita Peoples: Ancestors of the Oceanic World. Blackwell, Cambridge.

491 Kirch, P.V., Hunt, T.L., 1993. The To'aga Site: Three Millennia of Polynesian Occupation in the 492 Manu'a Islands, American Samoa. Contributions of the University of California Archaeological 493 Research Facility No. 51, Berkeley.

494 Moore, J.R., Kennedy, J., 1999. Results of an Archaeological Cultural Resource Evaluation for 495 the East and West Tutuila Water Line Project, Tutuila Island, American Samoa. Hale'iwa, HI: 496 Archaeological Consultants of the Pacific, Inc. 
Nothdurft, L.D., Webb, G.E., 2009. Earliest diagenesis in scleractinian coral skeletons: implications for palaeoclimate-sensitive geochemical archives. Facies 55, 161-201.

Nunn P.D., Petchey, F.J., 2013. Bayesian re-evaluation of Lapita settlement in Fiji: Radiocarbon analysis of the Lapita occupation at Bourewa and nearby sites on the Rove Peninsula, Viti Levu Island. Journal of Pacific Archaeology 4, 21-34.

Petchey, F.J., 2001. Radiocarbon determinations from the Mulifanua Lapita site, Upolu, Western Samoa. Radiocarbon 43, 63-68.

Petchey, F.J., Spriggs, M., Bedford, S., Valentin, F., Buckley, H., 2014. Radiocarbon dating of burials from the Teouma Lapita cemetery, Efate, Vanuatu. Journal of Archaeological Science 50, $227-242$.

507 Petchey, F.J., Spriggs, M., Bedford, S., Valentin, F., 2015. The chronology of occupation at 508 Teouma, Vanuatu: use of a modified chronometric hygiene protocol and Bayesian modeling to 509 evaluate midden remains. Journal of Archaeological Science: Reports 4, 95-105

510 Quintus, S., Clark, J.T., Day, S.S., Schwert, D.P., 2015. Landscape evolution and human 511 settlement patterns on Ofu Island, Manu'a Group, American Samoa. Asian Perspectives, in press

512 Reimer, P.J., Bard, E., Bayliss, A., Beck, J.W., Blackwell, P.G., Bronk Ramsey, C., Buck, C.E., 513 Cheng, H., Edwards, R.L., Friedrich, M., Grootes, P.M., Guilderson, T.P., Haflidason, H., 514 Hajdas, I., Hatté, C., Heaton, T.J., Hoffmann, D.L., Hogg, A.G., Hughen, K.A., Kaiser, K.F., 515 Kromer, B., Manning, S.W., Niu, M., Reimer, R.W., Richards, D.A., Scott, E.M., Southon, J.R., 516 Staff, R.A., Turney, C.S.M., van der Plicht, J., 2013. IntCal13 and Marine13 radiocarbon age 517 calibration curves 0-50,000 years cal BP. Radiocarbon 55, 1869-1887.

518 Rieth, T.M., 2007. A radiocarbon chronology for Samoa: an application of a chronometric 519 hygiene protocol to examine initial colonization and the "dark ages". Unpublished M.A. thesis, 520 Department of Anthropology, University of Hawai' $i$.

521 Rieth, T.M., Cochrane, E.E., 2012. Archaeological Monitoring and Data Recovery in Support of 522 the Federal Emergency Management Agency Permanent Housing Construction Program, Tutuila 523 Island, American Samoa. International Archaeological Research Institute, Inc. Honolulu, Hawaii, 524 Prepared for the Department of Homeland Security, Federal Emergency Management Agency.

525 Rieth, T.M., \& T.L. Hunt, 2008. A radiocarbon chronology for Samoan prehistory. Journal of 526 Archaeological Science 35, 1901-1927.

527 Rieth, T.M., Morrison, A.E., Addison, D.J., 2008. The temporal and spatial patterning of the 528 initial settlement of Sāmoa. Journal of Island and Coastal Archaeology 3, 214-239. 
529 Scholz, D., Mangini, A., 2007. How precise are U-series coral ages? Geochimica et

530 Cosmochimica Acta 71, 1935-1948.

531 Sheppard, P.J., 2011. Lapita Colonization across the Near/Remote Oceania Boundary. Current 532 Anthropology 52, 799-840.

533 Sheppard, P.J., Chiu, C., Walter, R., 2015. Re-dating Lapita movement into Remote Oceania.

534 Journal of Pacific Archaeology 6, 26-36.

535 Sheppard, P.J., R. Walter. 2006. A Revised Model of Solomon Islands Culture History. Journal 536 of the Polynesian Society 115, 47-76.

537 Specht, J., Denham, T., Goff, J., Terrell, J.E., 2014. Deconstructing the Lapita Cultural Complex 538 in the Bismarck Archipelago. Journal of Archaeological Research 22, 89-140

539 Weisler, M.I., Collerson, K., Feng, Y.X., Zhao, J-x, Yu, K-f, 2006. Thorium-230 coral

540 chronology of a late prehistoric Hawaiian chiefdom. Journal of Archaeological Science 33, 273541282.

542 Weisler, M.I., Hua, Q., Zhao, J-x, 2009. Late Holocene ${ }^{14} \mathrm{C}$ marine reservoir corrections for 543 Hawai'i derived from U-series dated archaeological coral. Radiocarbon 51, 955-968.

544 Weisler, M. I., Yamano, H., Hua, Q., 2012. A multidisciplinary approach for dating human 545 colonization of Pacific atolls. Journal of Island and Coastal Archaeology 7, 102-125. 
Table 1. Description of radiocarbon dates from Ofu Island used in this analysis. To'aga dates are recalibrated based on data presented by Kirch (1993a).

\begin{tabular}{|c|c|c|c|c|c|c|c|c|c|}
\hline $\begin{array}{l}\text { Sample } \\
\text { Number }\end{array}$ & Site & Unit & Layer & Depth & $\begin{array}{c}\text { Mater } \\
\text { ial }\end{array}$ & Taxon & $\begin{array}{l}13 \mathrm{c} / \\
12 \mathrm{c}\end{array}$ & $\begin{array}{c}\text { Conventi } \\
\text { onal } \\
\text { Date }\end{array}$ & $\begin{array}{c}\text { Calibrate } \\
\text { Date } \\
(95.4 \%)\end{array}$ \\
\hline $\begin{array}{l}\text { Beta- } \\
35602\end{array}$ & $\begin{array}{c}\text { To'ag } \\
\text { a }\end{array}$ & $\begin{array}{l}\text { Unit } \\
23\end{array}$ & Layer IIIA & NA & $\begin{array}{c}\text { Charc } \\
\text { oal }\end{array}$ & $\begin{array}{l}\text { Unidentified } \\
\text { charcoal }\end{array}$ & -26.9 & $\begin{array}{c}2630 \pm 10 \\
0\end{array}$ & $\begin{array}{c}2958-2380 \\
\text { BP }\end{array}$ \\
\hline $\begin{array}{l}\text { Beta- } \\
26464\end{array}$ & $\begin{array}{c}\text { To'ag } \\
\text { a }\end{array}$ & $\begin{array}{l}\text { Unit } \\
10\end{array}$ & Layer IIb & $\begin{array}{c}70-80 \\
\mathrm{BS}\end{array}$ & $\begin{array}{c}\text { Charc } \\
\text { oal }\end{array}$ & $\begin{array}{c}\text { Unidentified } \\
\text { charcoal (flecks) }\end{array}$ & -27.8 & $\begin{array}{c}2620 \pm 14 \\
0\end{array}$ & $\begin{array}{c}3057-2351 \\
\text { BP }\end{array}$ \\
\hline $\begin{array}{l}\text { Beta- } \\
35603\end{array}$ & $\begin{array}{c}\text { To'ag } \\
\text { a }\end{array}$ & $\begin{array}{l}\text { Unit } \\
23\end{array}$ & Layer IIIB & $\begin{array}{c}190- \\
260 \mathrm{BS}\end{array}$ & $\begin{array}{c}\text { Charc } \\
\text { oal }\end{array}$ & $\begin{array}{l}\text { Unidentified } \\
\text { charcoal }\end{array}$ & -28.4 & $\begin{array}{c}2600 \pm 17 \\
0\end{array}$ & $\begin{array}{c}3156-2314 \\
\text { BP }\end{array}$ \\
\hline $\begin{array}{l}\text { Beta- } \\
35601\end{array}$ & $\begin{array}{c}\text { To'ag } \\
\text { a }\end{array}$ & $\begin{array}{l}\text { Unit } \\
28\end{array}$ & Layer II & $\begin{array}{c}290- \\
300 \mathrm{BS}\end{array}$ & $\begin{array}{c}\text { Charc } \\
\text { oal }\end{array}$ & $\begin{array}{c}\text { Unidentified } \\
\text { charcoal (flecks) }\end{array}$ & -27.8 & $\begin{array}{c}2900 \pm 11 \\
0\end{array}$ & $\begin{array}{c}3177-2781 \\
\text { BP }\end{array}$ \\
\hline $\begin{array}{c}\text { Beta- } \\
\text { 249325* }\end{array}$ & $\begin{array}{c}\mathrm{Va}^{6} \text { ot } \\
\mathrm{o}\end{array}$ & $\begin{array}{c}35 \mathrm{E} / 1 \\
6 \mathrm{~N}\end{array}$ & $\begin{array}{l}\text { Layer IIb, } \\
\text { level } 5\end{array}$ & $97 \mathrm{BD}$ & $\begin{array}{l}\text { Charc } \\
\text { oal }\end{array}$ & $\begin{array}{l}\text { Unidentified } \\
\text { charcoal }\end{array}$ & -25.9 & $2200 \pm 40$ & $\begin{array}{c}2330-2120 \\
\text { BP }\end{array}$ \\
\hline $\begin{array}{c}\text { Beta- } \\
128705\end{array}$ & $\begin{array}{c}\mathrm{Va}^{6} \text { ot } \\
\mathrm{o}\end{array}$ & $\begin{array}{c}23 \mathrm{E} / 6 \\
\mathrm{~N}\end{array}$ & $\begin{array}{l}\text { Layer IIc, } \\
\text { level } 7\end{array}$ & $\begin{array}{c}72-74 \\
\mathrm{BD}\end{array}$ & $\begin{array}{c}\text { Charc } \\
\text { oal }\end{array}$ & $\begin{array}{l}\text { Unidentified } \\
\text { charcoal }\end{array}$ & -25.8 & $2230 \pm 40$ & $\begin{array}{c}2337-2151 \\
\text { BP }\end{array}$ \\
\hline $\begin{array}{c}\text { Beta- } \\
297826\end{array}$ & $\begin{array}{c}\mathrm{Va}^{6} \text { ot } \\
\mathrm{o}\end{array}$ & $\begin{array}{c}37 \mathrm{E} / 9 \\
\mathrm{~N}\end{array}$ & V Feature 60 & $144 \mathrm{BD}$ & $\begin{array}{c}\text { Charc } \\
\text { oal }\end{array}$ & $\begin{array}{l}\text { Unidentified } \\
\text { charcoal }\end{array}$ & -26.2 & $2280 \pm 40$ & $\begin{array}{c}2354-2157 \\
\text { BP }\end{array}$ \\
\hline $\begin{array}{c}\text { Beta- } \\
\mathbf{3 6 6 7 3 0}\end{array}$ & $\begin{array}{c}\mathrm{Va}^{6} \text { ot } \\
\mathrm{o}\end{array}$ & $\begin{array}{c}39 \mathrm{E} / 9 \\
\mathrm{~N}\end{array}$ & Feature 74 & $129 \mathrm{BD}$ & $\begin{array}{c}\text { Charc } \\
\text { oal }\end{array}$ & $\begin{array}{l}\text { Cordyline sp. } \\
\text { Stem }\end{array}$ & $\begin{array}{c}- \\
28.0 \\
0\end{array}$ & $2350 \pm 30$ & $\begin{array}{c}2464-2324 \\
\text { BP }\end{array}$ \\
\hline $\begin{array}{c}\text { Beta- } \\
\mathbf{3 6 6 7 2 9}\end{array}$ & $\begin{array}{c}\mathrm{Va}^{6} \text { ot } \\
\mathrm{o}\end{array}$ & $\begin{array}{c}40 \mathrm{E} / 9 \\
\mathrm{~N}\end{array}$ & Vc & $121 \mathrm{BD}$ & $\begin{array}{l}\text { Charc } \\
\text { oal }\end{array}$ & $\begin{array}{l}\text { Cocos nucifera } \\
\text { endocarp }\end{array}$ & $\begin{array}{c}- \\
25.3 \\
0\end{array}$ & $2350 \pm 30$ & $\begin{array}{c}2464-2324 \\
\text { BP }\end{array}$ \\
\hline $\begin{array}{c}\text { Beta- } \\
262551\end{array}$ & $\begin{array}{c}\mathrm{Va}^{6} \text { ot } \\
\mathrm{o}\end{array}$ & $\begin{array}{l}35 \mathrm{E} / 1 \\
2 \mathrm{~N}\end{array}$ & $\begin{array}{l}\text { Layer IV, } \\
\text { Feature } 25\end{array}$ & $\begin{array}{c}103- \\
113 \mathrm{BD}\end{array}$ & $\begin{array}{c}\text { Charc } \\
\text { oal }\end{array}$ & $\begin{array}{l}\text { Unidentified } \\
\text { charcoal }\end{array}$ & -28.0 & $2320 \pm 50$ & $\begin{array}{c}2652-2155 \\
\text { BP }\end{array}$ \\
\hline $\begin{array}{c}\text { Beta- } \\
120417\end{array}$ & $\begin{array}{c}\mathrm{Va}^{6} \text { ot } \\
\mathrm{o}\end{array}$ & $\begin{array}{c}24 \mathrm{E} / 2 \\
\mathrm{~N}\end{array}$ & $\begin{array}{l}\text { Layer IIIc, } \\
\text { Feature } 12\end{array}$ & $\begin{array}{c}114- \\
117 \mathrm{BD}\end{array}$ & $\begin{array}{c}\text { Charc } \\
\text { oal }\end{array}$ & $\begin{array}{l}\text { Unidentified } \\
\text { charcoal }\end{array}$ & $\begin{array}{c}- \\
27.2 \\
0\end{array}$ & $2370 \pm 50$ & $\begin{array}{c}2700-2312 \\
\text { BP }\end{array}$ \\
\hline $\begin{array}{c}\text { Beta- } \\
\text { 249326* }\end{array}$ & $\begin{array}{c}\mathrm{Va}^{6} \mathrm{ot} \\
\mathrm{o}\end{array}$ & $\begin{array}{c}28 \mathrm{E} / 8 \\
\mathrm{~N}\end{array}$ & $\begin{array}{c}\text { Layer IV, } \\
\text { level } 7, \\
\text { Feature } 39\end{array}$ & $99 \mathrm{BD}$ & $\begin{array}{c}\text { Charc } \\
\text { oal }\end{array}$ & $\begin{array}{l}\text { Unidentified } \\
\text { charcoal }\end{array}$ & $\begin{array}{c}- \\
25.4 \\
0\end{array}$ & $2430 \pm 40$ & $\begin{array}{c}2702-2353 \\
\text { BP }\end{array}$ \\
\hline $\begin{array}{c}\text { Beta- } \\
297824\end{array}$ & $\begin{array}{c}\mathrm{Va}^{6} \text { ot } \\
\mathrm{o}\end{array}$ & $\begin{array}{c}36 \mathrm{E} / 7 \\
\mathrm{~N}\end{array}$ & V Feature 59 & $133 \mathrm{BD}$ & $\begin{array}{c}\text { Charc } \\
\text { oal }\end{array}$ & $\begin{array}{l}\text { Unidentified } \\
\text { charcoal }\end{array}$ & -25.1 & $2520 \pm 30$ & $\begin{array}{c}2744-2491 \\
\text { BP }\end{array}$ \\
\hline $\begin{array}{c}\text { Beta- } \\
\text { 249327* }\end{array}$ & $\begin{array}{c}\mathrm{Va}^{6}{ }^{\circ} \\
\mathrm{o}\end{array}$ & $\begin{array}{c}23 \mathrm{E} / 1 \\
0 \mathrm{~N}\end{array}$ & $\begin{array}{l}\text { Layer IVb, } \\
\text { level } 6\end{array}$ & $\begin{array}{l}\text { 98-108 } \\
\text { BD }\end{array}$ & $\begin{array}{c}\text { Charc } \\
\text { oal }\end{array}$ & $\begin{array}{l}\text { Unidentified } \\
\text { charcoal }\end{array}$ & $\begin{array}{c}- \\
22.2 \\
0\end{array}$ & $2520 \pm 40$ & $\begin{array}{c}2747-2470 \\
\text { BP }\end{array}$ \\
\hline $\begin{array}{c}\text { Beta- } \\
128706\end{array}$ & $\begin{array}{c}\mathrm{Va}^{6} \mathrm{ot} \\
\mathrm{o}\end{array}$ & $\begin{array}{l}24 \mathrm{E} / 1 \\
8 \mathrm{~N}\end{array}$ & $\begin{array}{l}\text { Layer IVG, } \\
\text { level } 15\end{array}$ & $169 \mathrm{BD}$ & $\begin{array}{l}\text { Charc } \\
\text { oal }\end{array}$ & $\begin{array}{l}\text { Unidentified } \\
\text { charcoal }\end{array}$ & $\begin{array}{c}- \\
30.3 \\
0\end{array}$ & $2460 \pm 40$ & $\begin{array}{c}2710-2364 \\
\text { BP }\end{array}$ \\
\hline $\begin{array}{c}\text { Beta- } \\
\mathbf{3 0 8 9 7 8}\end{array}$ & $\begin{array}{c}\text { Coco } \\
\text { nut } \\
\text { Grove }\end{array}$ & XU-2 & II & $56 \mathrm{BD}$ & $\begin{array}{c}\text { Charc } \\
\text { oal }\end{array}$ & $\begin{array}{l}\text { Unidentified } \\
\text { charcoal }\end{array}$ & -27.7 & $2370 \pm 30$ & $\begin{array}{c}2489-2337 \\
\text { BP }\end{array}$ \\
\hline $\begin{array}{c}\text { Beta- } \\
\mathbf{3 0 7 4 7 3}\end{array}$ & $\begin{array}{l}\text { Coco } \\
\text { nut } \\
\text { Grove }\end{array}$ & XU-2 & III & $67 \mathrm{BD}$ & $\begin{array}{l}\text { Charc } \\
\text { oal }\end{array}$ & $\begin{array}{l}\text { Cocos nucifera } \\
\text { endocarp }\end{array}$ & -24.9 & $2470 \pm 30$ & $\begin{array}{c}2717-2380 \\
\text { BP }\end{array}$ \\
\hline $\begin{array}{c}\text { Beta- } \\
\mathbf{3 5 4 1 3 7}\end{array}$ & $\begin{array}{c}\text { Ofu } \\
\text { Villag } \\
\text { e }\end{array}$ & XU-4 & VIc & $301 \mathrm{BD}$ & $\begin{array}{c}\text { Charc } \\
\text { oal }\end{array}$ & $\begin{array}{l}\text { Cocos nucifera } \\
\text { endocarp }\end{array}$ & -23.0 & $2490 \pm 30$ & $\begin{array}{c}2730-2460 \\
\text { BP }\end{array}$ \\
\hline $\begin{array}{c}\text { Beta- } \\
383081\end{array}$ & $\begin{array}{c}\text { Ofu } \\
\text { Villag } \\
\text { e }\end{array}$ & XU-4 & VIc & $226 \mathrm{BD}$ & $\begin{array}{c}\text { Charc } \\
\text { oal }\end{array}$ & $\begin{array}{c}\text { Cocos nucifera } \\
\text { endocarp }\end{array}$ & $\begin{array}{c}- \\
23.4 \\
0\end{array}$ & $2490 \pm 30$ & $\begin{array}{c}2730-2460 \\
\text { BP }\end{array}$ \\
\hline
\end{tabular}


Table 2. Lab numbers and provenance for U-series dated Acropora spp. corals from Va'oto, Ofu, 561 American Samoa. All lab numbers are preceded by 2014.

\begin{tabular}{|c|c|c|c|c|c|c|c|c|}
\hline $\begin{array}{l}\text { Lab } \\
\text { No. }\end{array}$ & Site & Unit & $\begin{array}{l}\text { Lay } \\
\text { er }\end{array}$ & Level & $\begin{array}{l}\text { Depth } \\
\text { (cmbd) }\end{array}$ & $\begin{array}{l}\text { Weight } \\
\text { (g) }\end{array}$ & Condition & $\begin{array}{l}\text { Calibrated } \\
\text { Date (BP) }\end{array}$ \\
\hline 15 & $\begin{array}{l}\text { Coconut } \\
\text { Grove }\end{array}$ & 11 & III & 6 & 64 & 8.5 & Unmodified & $2814-2778$ \\
\hline 16 & Va'oto & $24 \mathrm{E} / 18 \mathrm{~N}$ & $\mathrm{IVb}$ & 15 & $161-171$ & 382.9 & Abrader & $2486-2454$ \\
\hline 17 & Va'oto & $37 \mathrm{E} / 11 \mathrm{~N}$ & III & 5 & 82 & 55.1 & Unmodified & $2363-2323$ \\
\hline 18 & Va'oto & $\mathrm{T} 1$ & V & - & $130-150$ & 9.2 & Unmodified & $3147-3103$ \\
\hline 19 & $\begin{array}{l}\text { Coconut } \\
\text { Grove }\end{array}$ & 12 & III & 8 & 59 & 3.0 & Unmodified & $2692-2640$ \\
\hline 20 & Va'oto & $40 \mathrm{E} / 9 \mathrm{~N}$ & $\mathrm{Vb}$ & 10 & 106 & 4.6 & Unmodified & $2392-2356$ \\
\hline 21 & Va'oto & $40 \mathrm{E} / 9 \mathrm{~N}$ & $\mathrm{Vb}$ & 10 & 102 & 11.6 & Unmodified & $2395-2359$ \\
\hline 22 & Va'oto & $39 \mathrm{E} / 9 \mathrm{~N}$ & VI & - & $134-187$ & 12.2 & Unmodified & $2397-2356$ \\
\hline 23 & Va'oto & $39 \mathrm{E} / 9 \mathrm{~N}$ & VI & - & $134-187$ & 26.1 & Unmodified & $2517-2489$ \\
\hline 24 & $\mathrm{Va}^{6}$ oto & $32 \mathrm{E} / 8 \mathrm{~N}$ & $\mathrm{IVb}$ & 7 & $90-100$ & 3.3 & Abrader & $2385-2345$ \\
\hline
\end{tabular}

